\begin{tabular}{|c|c|}
\hline & $\begin{array}{c}\text { Journal of } \\
\text { Arid } \\
\text { Environments }\end{array}$ \\
\hline & cate/jariden \\
\hline
\end{tabular}

\title{
Implications of restricted access to grazing by cattle in wet season in the Sahel
}

\author{
A.A. Ayantunde ${ }^{\mathrm{a}, *}$, S. Fernández-Rivera ${ }^{\mathrm{b}}$, P.H. Hiernaux ${ }^{\mathrm{c}}$, R. Tabo ${ }^{\mathrm{d}}$ \\ ${ }^{\mathrm{a}}$ International Livestock Research Institute, ILRI/ICRISAT, B.P. 12404, Niamey, Niger \\ ${ }^{\mathrm{b}}$ International Livestock Research Institute, P.O. Box 5689, Addis Ababa, Ethiopia \\ ${ }^{\mathrm{c}}$ Centre d'Etudes Spatiales de la Biosphère (CESBIO), 18 avenue Edouard Belin, bpi 2801, F-31041 Toulouse Cedex 4, France \\ ${ }^{\mathrm{d}}$ International Crops Research Institute for the Semi-Arid Tropics (ICRISAT), B.P. 12404, Niamey, Niger
}

Received 23 February 2007; received in revised form 16 May 2007; accepted 12 June 2007

Available online 31 July 2007

\begin{abstract}
To address the problem of restricted access to grazing by cattle in wet season in the Sahel, a grazing trial was conducted to study the effect of duration of grazing and grazing method on cattle nutrition and performance. Twenty-four intact steers weighing $259 \mathrm{~kg}(\mathrm{SD}=62)$ were randomly allotted to four treatments to study the effect of the combination of grazing method (tethering and close herding) and grazing duration (6 and $9 \mathrm{~h}$ per day) on diet selection, faecal output, forage intake, grazing behaviour and weight changes in the wet season. Three esophageally fistulated steers were used in a cross-over design to sample diet selected by tethered and herded animals. Extrusa samples from esophageally fistulated steers and faecal output from intact steers were collected in weeks 6 and 9 of the experiment and grazing behaviour of the intact steers was observed in week 6 . Tethered animals selected diets of lower organic matter digestibility (OMD) but tethering had no significant effect on crude protein. Close herded steers consistently consumed more forage than those tethered in both periods. Both grazing method and duration had significant effect on ingestion rate by the steers. Tethered steers had lower average daily gain than those herded. The results demonstrate that the common practice of tethering sedentary cattle in the wet season in the southern Sahel in West Africa reduces forage intake and consequently average daily gain.

(C) 2007 Elsevier Ltd. All rights reserved.
\end{abstract}

Keywords: Diet selection; Forage intake; Grazing; Herd management; Tethering

\section{Introduction}

Following rapid population growth since the 1950s, there has been increase in area of land cropped in West African Sahel (Turner et al., 2005). Cropping areas have expanded into marginal and grazing lands (Powell et al., 1996), and access to communal grazing areas is becoming increasingly restricted, especially in the wet season, due to fragmentation of cultivated fields. In the wet season, the common practice in the region is to send the animals on transhumance to pastoral zones in the northern Sahel where the animals remain until

*Corresponding author. Tel.: + 22720722529 ; fax: + 22720734329 .

E-mail address: a.a.ayantunde@cgiar.org (A.A. Ayantunde). 
harvest of crops in the southern Sahel (Fernández-Rivera et al., 2003; Thebaud and Batterbury, 2001; Turner and Hiernaux, 2002). However, a significant number of animals do not go on transhumance in wet season (Turner and Hiernaux, 2002).

According to the survey conducted in Fakara in South-western Niger in1998 on the practice of wet season transhumance, about $43 \%$ of the households managing herds of cattle, sheep and goats did not practice transhumance (Hiernaux and Ayantunde, 2004). Thus, resident livestock in the southern Sahel in wet season are restricted to grazing areas of uncultivable lands, fallows and roadsides. The grazing pressure is always high during this period because of restricted access to grazing lands and low standing herbage biomass at the onset of the wet season.

During the wet season, sedentary animals are often closely herded to prevent damage to crops (Turner et al., 2005). Some animals are stall-fed with weeds, browses, crop residues from the previous year and crop byproducts while some others are tethered in fallow lands for grazing (Fernández-Rivera et al., 2005; Hiernaux and Ayantunde, 2004). Tethering is justified not only to prevent damage to crops but also to address lack of herding labour as most farmers are busy with cropping activities (Turner and Hiernaux, 2002). Due to labour shortage during the cropping season the duration of grazing is often short (Ayantunde et al., 2001; Turner et al., 2005). Restricted access to grazing may have nutritional implications for the grazing ruminants in terms of foraging behaviour, forage intake and animal performance. Quality of the diet selected may also be affected as tethered animals may have less opportunity for selective grazing. Under-nutrition of the grazing ruminants in the wet season, when grazing resources are of the best quality, due to restricted access to grazing may not only affect animal performance in the wet season but also the overall condition and productivity of the animals, especially reproductive performance of the females. Beyond the possible effect in wet season of restricted access to grazing on the animal performance, survivability in the dry season due to feed scarcity may be also affected.

Therefore, a good understanding of the nutritional implications of restricted access to grazing by cattle in wet season is necessary for better management of sedentary herds and grazing resources in the region. The objective of this study was to determine the effect of restricted access (in terms of duration of grazing and tethering) to grazing by cattle on diet selection, forage intake, feeding behaviour, and weight changes during the rainy season.

\section{Materials and methods}

\subsection{Study site}

The experiment was carried out during the wet season over 11 weeks (July to September 2005) at International Crop Research Institute for the Semi-Arid Tropics (ICRISAT-SC) in Sadoré $\left(13^{\circ} 14^{\prime} \mathrm{N}, 2^{\circ} 16^{\prime} \mathrm{E}\right)$, Niger. Annual precipitation for 2005 when the study was conducted was $536 \mathrm{~mm}$. Rains began to fall on 31 May and stopped on October 4. The experimental paddock was a fallow dominated by annual grasses, which had not been grazed for more than 5 years. The soils in the paddock are largely sandy (90-95\%), poor in organic matter content $(0.15-0.2 \%$ organic $\mathrm{C})$ and acidic $(\mathrm{pH}$ water $4.6-5.0)$, and are weakly structured (Hiernaux et al., 1999).

\subsection{Treatments, pastures and animals}

Twenty-four intact steers of Bororo breed with a mean body weight $(W)$ of $259 \mathrm{~kg}(\mathrm{SD}=62)$ were randomly allotted to four treatments defined by factorial combinations of two levels of grazing method (tethering in the grazing site and close herding) and two levels of grazing duration ( 6 and $9 \mathrm{~h}$ per day). The age of the steers ranged between 2 and 3 years. Grazing by the steers began at 08:00 and 11:00, respectively, for 9 and $6 \mathrm{~h}$ of grazing duration. All animals returned to a barn, which was about $500 \mathrm{~m}$ from the experimental paddock at 17:00 and were individually penned. Animals in the tethering treatments were individually tied with a $6 \mathrm{~m}$ rope to a peg driven into the ground at the grazing site. The tethering location was changed every $3 \mathrm{~h}$. In this paper, $6 \mathrm{~h}$ tethered, $6 \mathrm{~h}$ close herded, $9 \mathrm{~h}$ tethered and $9 \mathrm{~h}$ close herded treatments will be referred to as T6, H6, T9 and H9, respectively. 
The experimental paddock was a fallow of 40 ha dominated by annual grasses mainly Ctenium elegans, Brachiara xantholeuca, Schoenefeldia gracilis and forbs mainly Zornia glochidiata, Alysicarpus ovalifolius and Cassia mimosoides. The paddock was divided into four fenced parcels of 10 ha each and the treatments were randomly allotted to the parcels for grazing throughout the experimental period. The reason for this was to eliminate any likely effect of social facilitation and group synchronization of grazing behaviour among animals from different treatments. For example, if all the animals were to graze together, those in the herding groups might stay around the tethered steers to graze. At peak vegetative stage (last week in August), the mean standing herbage in the experimental paddock was estimated at $1710(\mathrm{SE}=56) \mathrm{kg} \mathrm{DM} \mathrm{ha}^{-1}$. Herbage biomass was measured according to the destructive technique suggested by Hiernaux (1996) for Sahelian rangelands. Standing herbage in the parcels grazed by T6, H6, T9 and H9 was estimated at $2180(\mathrm{SE}=75), 1501$ $(\mathrm{SE}=39), 1510(\mathrm{SE}=29)$ and $1648(\mathrm{SE}=59) \mathrm{kg} \mathrm{DM} \mathrm{ha}^{-1}$, respectively, which suggested that forage availability was not a constraint during the experimental period. The nutritional quality of the standing herbage is presented in Table 1.

The study included two periods of collection of faeces and extrusa samples, which started in weeks 6 and 9 of the experiment. Week 6 was in the middle of wet season, which corresponded with peak vegetative stage of the herbaceous plants while week 9 was towards the end of wet season. Each period included 9 days of faecal collection. The animals were accustomed to carrying faecal collection bags during the last week before the collection started. In each collection period, faecal bags were emptied and the faeces weighed, before and after grazing. Ten percent of the faecal excretion was sampled and frozen for subsequent analysis. The animals were watered in the morning $30 \mathrm{~min}$ before grazing started. In addition, water was provided in two watering troughs placed at the entrance of each parcel. Animals in the herding treatments were free to drink from the watering troughs at any time. Those in tethered treatments were allowed to drink from the watering troughs each time the tethering location was changed before they were tied. In week 6 of the experiment the grazing activities of all steers were observed. Observation was made every 5 min during the period of grazing only for 3 consecutive days by four observers. The observation was instantaneous and the recording included one of the following activities: searching for food, prehending, masticating, walking, resting, drinking, fighting and socializing. Eating time was defined as the time spent prehending, masticating and searching for food. Activities such as drinking, fighting and socializing were referred to as 'other'.

In the two collection periods (weeks 6 and 9), three esophageally fistulated steers were used for sampling the diet selected by each treatment in a switch-over design. The fistulated steers were of the same breed and age as the intact steers. All the three esophageally fistulated steers first grazed with $9 \mathrm{~h}$ close herding treatment, then extrusa samples were collected for 2 consecutive days at 09:00, 11:30 and 14:30. After two days of adaptation with $6 \mathrm{~h}$ close herding treatment, extrusa samples were collected at 11:30 and 14:30 for 2 consecutive days. Then, the steers were switched to $9 \mathrm{~h}$ tethering treatment and were allowed 9 days of adaptation before extrusa collection for 3 times a day (09:00, 11:30 and 14:30) for 2 consecutive days.

Table 1

Nutritional quality $\left(\mathrm{g} \mathrm{kg}^{-1} \mathrm{DM}\right)$ of standing herbage at peak vegetative stage (August 2005)

\begin{tabular}{lll}
\hline Component & Mean & SE \\
\hline Organic matter & 932 & 8 \\
Crude protein & 114 & 5 \\
Phosphorus & 2.2 & 0.2 \\
NDF & 725 & 27 \\
ADF & 513 & 18 \\
Lignin & 110 & 8 \\
Hemicellulose & 212 & 15 \\
Cellulose & 403 & 17 \\
Organic matter digestibility & 573 & 26 \\
Digestible organic matter & 531 & 22 \\
\hline
\end{tabular}

Note: Digestible organic matter $=$ organic matter digestibility $\times$ organic matter. 
The three steers were then grazed with $6 \mathrm{~h}$ tethering group and after 2 days of adaptation extrusa samples were collected twice per day (11:30 and 14:30) for 2 consecutive days. Similar grazing schedule was followed in week 9 but the animals first started grazing with $9 \mathrm{~h}$ tethering treatment. The extrusa samples were frozen immediately after collection.

\subsection{Sample processing and laboratory analyses}

The daily faecal sub-samples were bulked by time of collection (before or after grazing) and analysed for dry $(\mathrm{DM})$ and organic matter (OM). The extrusa samples were dried at $55^{\circ} \mathrm{C}$ for $48 \mathrm{~h}$ and were ground to pass a 1-mm screen. They were analysed for DM, OM, nitrogen (N), ashless neutral detergent fibre (NDF), ashless acid detergent fibre (ADF) and ashless lignin (Van Soest et al., 1991). Hemicellulose and cellulose were calculated as the differences NDF-ADF and ADF-lignin, respectively. Organic matter digestibility (OMD) was determined by the in vitro gas production technique calibrated with standards obtained in vivo (Menke et al., 1979). Standing herbage samples collected from vegetation survey in the last week of August 2005, representing the available forage were analysed for DM, OM, N, phosphorus (P), NDF, ADF, lignin and OMD.

\subsection{Animal measurements}

Animals were weighed every 2 weeks for 3 consecutive days. The animals were fasted prior to weighing. Average daily gain (ADG) was estimated by regression of individual body weight (W) data over time. Individual animal feed intake was estimated from individual data on faecal output and treatment means of OMD (Cordova et al., 1978).

\subsection{Data analysis}

Data analysis was performed with SAS (SAS, 1987) using the general linear model (GLM) procedure. An analysis of variance model including effects of grazing method (tethering and close herding) and grazing duration $(6$ and $9 \mathrm{~h}$ ) and the interaction between the two factors, was used to analyse data on faecal output, forage intake, animal behaviour (time spent eating, resting, walking, and other) and body weight changes. Extrusa data was analysed using analysis of variance model, which included effects of animal, collection time nested within animal, grazing method, grazing duration and the interaction between grazing method and grazing duration. $T$-test was used to contrast the extrusa data collected between the two periods. Unless otherwise specified, the level of significance was declared at $p<0.05$.

\section{Results}

\subsection{Forage quality and diet selection}

OMD of the herbage grazed in August 2005 (Table 1) was significantly lower than that of the diet (extrusa) selected in the same period (Table 2). However, there was no significant difference in crude protein of the herbage grazed and the diet selected. Increasing duration of grazing from 6 to $9 \mathrm{~h}$ per day significantly decreased crude protein content but increased NDF and ADF content in week 6 of extrusa collection whereas there was no significant effect of duration of grazing on OMD. There was significant interaction between duration of grazing and grazing method for organic matter, crude protein, NDF and ADF of the diet selected in week 6. In week 9, duration of grazing had no effect on both crude protein and OMD but on NDF and cellulose (Table 2). Tethered animals selected diet of lower crude protein and OMD in August 2005 (week 6). In September 2005 (week 9), tethering had no effect on crude protein of diet selected whereas it had significant effect on OMD. As the wet season progressed (week 6 vs. 9), crude protein and OMD of the diet selected declined while cellulose increased for all treatments. 
Table 2

Effect of grazing method (tethering and close herding) and duration of grazing (6 and $9 \mathrm{~h})$ on diet selection (extrusa; $\left.\mathrm{g} \mathrm{kg}^{-1} \mathrm{DM}\right) \mathrm{by}$ esophageally fistulated steers

\begin{tabular}{|c|c|c|c|c|c|c|c|c|}
\hline \multirow[t]{2}{*}{ Component } & \multicolumn{2}{|l|}{$6 \mathrm{~h}$} & \multicolumn{2}{|l|}{$9 \mathrm{~h}$} & \multirow[t]{2}{*}{ SE } & \multicolumn{3}{|l|}{$p$-values } \\
\hline & Tethered & Herded & Tethered & Herded & & Duration & Method & Interaction \\
\hline \multicolumn{9}{|l|}{ Week 6} \\
\hline Organic matter & 908 & 897 & 917 & 889 & 4 & NS & $<0.01$ & 0.05 \\
\hline Crude protein & 111 & 147 & 106 & 125 & 3 & $<0.01$ & 0.04 & 0.05 \\
\hline $\mathrm{NDF}$ & 691 & 655 & 804 & 693 & 13 & $<0.01$ & $<0.01$ & 0.02 \\
\hline $\mathrm{ADF}$ & 500 & 472 & 617 & 482 & 12 & $<0.01$ & $<0.01$ & $<0.01$ \\
\hline Lignin & 167 & 163 & 168 & 158 & 10 & NS & NS & NS \\
\hline Hemicellulose & 191 & 184 & 188 & 211 & 9 & NS & NS & NS \\
\hline Cellulose & 333 & 309 & 349 & 323 & 15 & NS & NS & NS \\
\hline OMD & 590 & 619 & 593 & 621 & 6 & NS & $<0.01$ & NS \\
\hline DOM & 536 & 555 & 544 & 553 & 6 & NS & 0.04 & NS \\
\hline \multicolumn{9}{|l|}{ Week 9} \\
\hline Organic matter & 921 & 905 & 904 & 890 & 6 & $<0.01$ & 0.01 & NS \\
\hline Crude protein & 95 & 96 & 99 & 97 & 3 & NS & NS & NS \\
\hline $\mathrm{NDF}$ & 764 & 754 & 694 & 692 & 22 & $<0.01$ & NS & NS \\
\hline $\mathrm{ADF}$ & 548 & 536 & 524 & 525 & 20 & NS & NS & NS \\
\hline Lignin & 124 & 155 & 146 & 160 & 8 & NS & $<0.01$ & NS \\
\hline Hemicellulose & 216 & 219 & 170 & 168 & 15 & $<0.01$ & NS & NS \\
\hline Cellulose & 425 & 380 & 383 & 370 & 15 & 0.03 & NS & NS \\
\hline OMD & 560 & 571 & 569 & 581 & 6 & NS & 0.034 & NS \\
\hline DOM & 516 & 517 & 514 & 517 & 6 & NS & NS & NS \\
\hline
\end{tabular}

Note: $\mathrm{OMD}=$ organic matter digestibility; DOM $=$ digestible organic matter $(\mathrm{OMD} \times$ organic matter $)$; NS $=$ not significant $(p>0.05)$. Animal and collection time of extrusa did not have significant effect $(p>0.05)$ on all the parameters.

Values for crude protein, cellulose, OMD and DOM were significantly different $(p<0.05)$ between the two periods (weeks 6 and 9 ) of extrusa collection.

Table 3

Effect of grazing method (tethering and close herding) and duration of grazing (6 and $9 \mathrm{~h})$ on daily faecal dry matter (DM), nitrogen and phosphorus excretion by steers

\begin{tabular}{|c|c|c|c|c|c|c|c|c|}
\hline \multirow[t]{2}{*}{ Variable } & \multicolumn{2}{|l|}{$6 \mathrm{~h}$} & \multicolumn{2}{|l|}{$9 \mathrm{~h}$} & \multirow[t]{2}{*}{$\mathrm{SE}$} & \multicolumn{3}{|l|}{$p$-values } \\
\hline & Tethered & Herded & Tethered & Herded & & Duration & Method & Interaction \\
\hline \multicolumn{9}{|l|}{ Week 6} \\
\hline $\mathrm{g} \mathrm{DM} \mathrm{animal}^{-1}$ & 1434 & 1660 & 1390 & 1651 & 139 & NS & NS & NS \\
\hline $\mathrm{g} \mathrm{DM} \mathrm{kg}^{-0.75} \mathrm{~W}$ & 27.6 & 32.3 & 29.5 & 32.7 & 1.2 & NS & $<0.01$ & NS \\
\hline g Nitrogen & 32.7 & 40.2 & 30.1 & 34.9 & 3.1 & NS & NS & NS \\
\hline g Phosphorus & 5.7 & 6.1 & 5.8 & 6.2 & 0.5 & NS & NS & NS \\
\hline \multicolumn{9}{|l|}{ Week 9} \\
\hline $\mathrm{g} \mathrm{DM}_{\text {animal }}{ }^{-1}$ & 1463 & 1737 & 1437 & 1832 & 156 & NS & 0.04 & NS \\
\hline $\mathrm{g} \mathrm{DM} \mathrm{kg}^{-0.75} \mathrm{~W}$ & 27.5 & 32.6 & 29.4 & 34.3 & 1.2 & NS & $<0.01$ & NS \\
\hline g Nitrogen & 23.7 & 32.5 & 25.7 & 32.4 & 2.4 & NS & $<0.01$ & NS \\
\hline g Phosphorus & 5.4 & 5.6 & 5.2 & 5.7 & 0.5 & NS & NS & NS \\
\hline
\end{tabular}

Note: Only values for nitrogen excretion $\left(\mathrm{g} \mathrm{day}^{-1}\right)$ were significantly different $(p<0.05)$ between the two periods $($ weeks 6 and 9$)$ of faecal collection. NS $=$ not significant $(p>0.05)$.

\subsection{Faecal output}

The duration of grazing had no effect on faecal output in both periods. However, tethered animals had significantly lower faecal output $\left(\mathrm{g} \mathrm{DM} \mathrm{kg}^{-0.75} \mathrm{~W}\right)$ in both periods (Table 3). Nitrogen excreted $\left(\mathrm{g} \mathrm{day}^{-1}\right)$ through faeces in week 9 by tethered steers was significantly lower than those herded (24.7 vs. 32.4; $\mathrm{SE}=2.4$; 
Table 4

Effect of grazing method (tethering and close herding) and duration of grazing (6 and $9 \mathrm{~h})$ on forage dry matter and digestible organic matter (DOM) intake by steers

\begin{tabular}{|c|c|c|c|c|c|c|c|c|}
\hline \multirow[t]{2}{*}{ Variable } & \multicolumn{2}{|l|}{$6 \mathrm{hr}$} & \multicolumn{2}{|l|}{$9 \mathrm{hr}$} & \multirow[t]{2}{*}{ SE } & \multicolumn{3}{|l|}{$p$-values } \\
\hline & Tethered & Herded & Tethered & Herded & & Duration & Method & Interaction \\
\hline \multicolumn{9}{|l|}{ Week 6} \\
\hline $\mathrm{g} \mathrm{DM}_{\text {animal }}{ }^{-1}$ & 3876 & 4841 & 3809 & 4973 & 396 & NS & 0.01 & NS \\
\hline $\mathrm{g} \mathrm{DM} \mathrm{kg}^{-0.75} \mathrm{~W}$ & 74.6 & 94.1 & 80.8 & 98.7 & 3.5 & NS & $<0.01$ & NS \\
\hline $\mathrm{g} \mathrm{DOM} \mathrm{animal}^{-1}$ & 1816 & 2367 & 1786 & 2385 & 190 & NS & $<0.01$ & NS \\
\hline $\mathrm{g} \mathrm{DOM} \mathrm{kg}^{-0.75} \mathrm{~W}$ & 34.9 & 46.0 & 37.9 & 47.3 & 1.7 & NS & $<0.01$ & NS \\
\hline \multicolumn{9}{|l|}{ Week 9} \\
\hline $\mathrm{g} \mathrm{DM}_{\text {animal }}{ }^{-1}$ & 3673 & 4544 & 3724 & 5020 & 410 & NS & $<0.01$ & NS \\
\hline $\mathrm{g} \mathrm{DM} \mathrm{kg}^{-0.75} \mathrm{~W}$ & 69.0 & 85.3 & 76.3 & 93.9 & 3.3 & 0.03 & $<0.01$ & NS \\
\hline $\mathrm{g} \mathrm{DOM} \mathrm{animal}^{-1}$ & 1640 & 2037 & 1667 & 2235 & 183 & NS & $<0.01$ & NS \\
\hline $\mathrm{g} \mathrm{DOM} \mathrm{kg}^{-0.75} \mathrm{~W}$ & 30.8 & 38.2 & 34.1 & 41.8 & 1.5 & 0.03 & $<0.01$ & NS \\
\hline
\end{tabular}

Note: Only variable g DOM kg ${ }^{-0.75} \mathrm{~W}$ was significantly different $(p<0.05)$ between the two periods (weeks 6 and 9$)$ of intake measurement. $\mathrm{NS}=$ not significant $(p>0.05)$.

$p<0.01)$. Except for nitrogen excretion $\left(\mathrm{gday}^{-1}\right)$, there was no difference between both periods for other faecal output variables.

\subsection{Forage intake, grazing behaviour and animal performance}

Close herded steers consistently consumed more forage than the tethered steers in both periods (Table 4). The duration of grazing had no effect on forage intake $\left(\mathrm{g} \mathrm{DM} \mathrm{kg}{ }^{-0.75} \mathrm{~W}\right.$ ) in August 2005 (week 6; 84.4 vs. 89.8, $\mathrm{SE}=3.5, p>0.05$ ) whereas intake increased significantly with duration of grazing toward the end of wet season (week 9; 77.2 vs. 85.1, $\mathrm{SE}=3.3, p=0.03$ ). Similar trend was observed for intake of digestible organic matter ( $\mathrm{g}$ DOM kg ${ }^{-0.75} \mathrm{~W}$ ) in both periods. As the wet season progressed (week $6 \mathrm{vs}$. 9), digestible organic matter intake $\left(\mathrm{g}\right.$ DOM kg${ }^{-0.75} \mathrm{~W}$ ) declined significantly (week $6=41.5$; week $9=36.2 ; \mathrm{SE}=1.2$ ).

The hourly distribution of time expenditure for eating (this included time spent for prehension, mastication and searching for food) showed similar trend for tethered and herded animals for 6 and $9 \mathrm{~h}$ grazing durations, respectively (Fig. 1). For $6 \mathrm{~h}$ duration, both the tethered and herded steers reached their peak of eating three hours after grazing started after which eating time declined. For $9 \mathrm{~h}$ duration there were two peak eating times. The first was second hour after grazing started and the second was the last hour of grazing. Eating time decreased between these two peaks. Eating time increased significantly with duration of grazing (Table 5) while tethered animals spent more time eating than those herded. Tethered animals spent higher proportion of the time allowed for grazing on eating (tethered vs. herded: $82.5 \%$ vs. $76.5 \%$ ). There was a significant interaction between grazing method and duration of grazing for time spent eating, indicating larger differences between tethered and herded animals during $9 \mathrm{~h}$ grazing. Resting time increased significantly with duration of grazing, indicating that herded animals rested more than those tethered. Both grazing method and duration of grazing had significant effects on ingestion rate (Table 5). Animals in $6 \mathrm{~h}$ duration of grazing had higher ingestion rates than those that grazed for $9 \mathrm{~h}$. For nine hours duration of grazing, tethered animals had lower ingestion rates than herded.

ADG $\left(\mathrm{g} \mathrm{day}^{-1}\right)$ by steers was 226 for T6, 320 for H6, 258 for T9 and 360 for H9. Whereas tethered animals had a significantly lower ADG than those herded (tethered vs. herded: 242 vs. $340 \mathrm{~g} \mathrm{day}^{-1}$; $\mathrm{SE}=38$ ), the duration of grazing had no effect (6h vs. 9 h: 273 vs. 309 g day $^{-1}$; $\mathrm{SE}=34$ ).

\section{Discussion}

The standing herbage mass estimated at $1710 \mathrm{~kg} \mathrm{DM} \mathrm{ha}^{-1}(\mathrm{SE}=56)$ at peak vegetative stage (August 2005) of the experimental paddock is comparable to $1951(\mathrm{SE}=131) \mathrm{kg} \mathrm{DM} \mathrm{ha}^{-1}$ at similar growth stage reported 

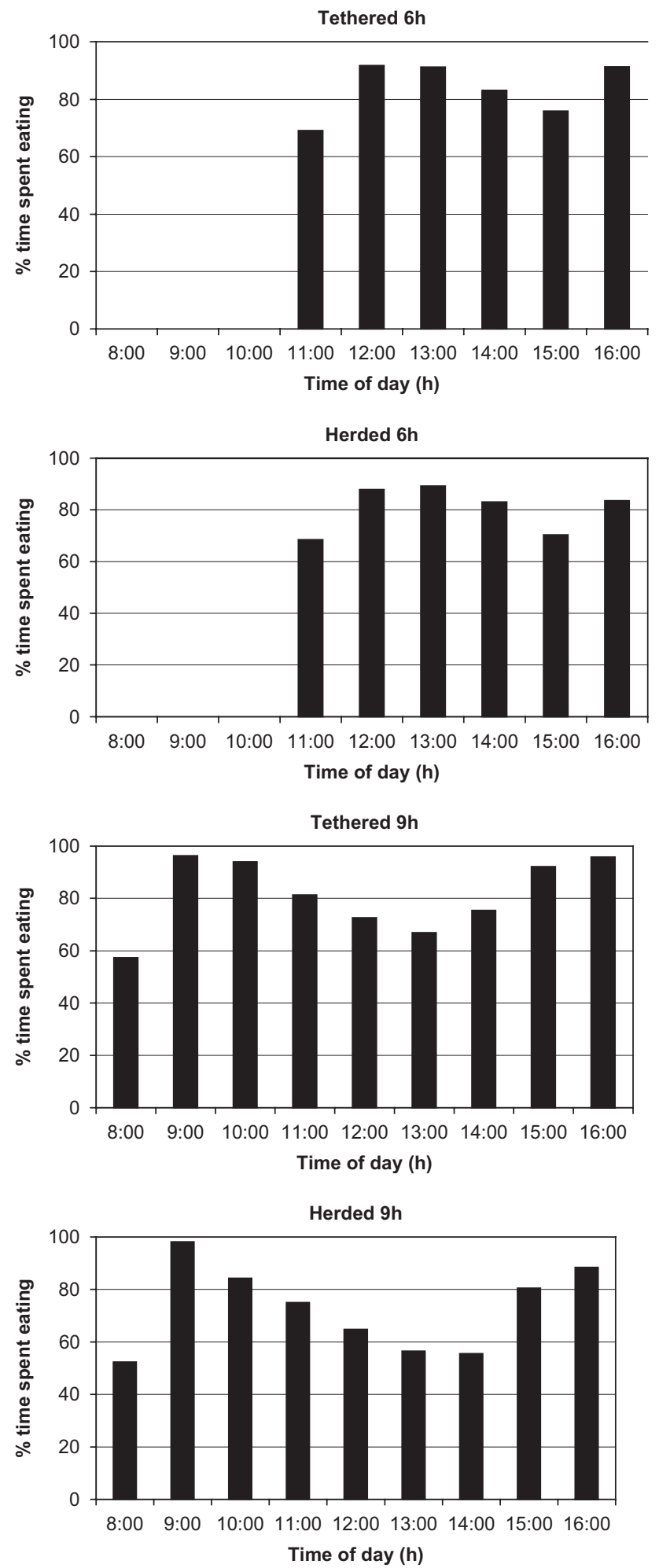

Fig. 1. Hourly distribution of time spent eating by the steers tethered for $6 \mathrm{~h}$, herded for $6 \mathrm{~h}$, tethered for $9 \mathrm{~h}$ and herded for $9 \mathrm{~h}$. 
Table 5

Effect of grazing method (tethering and close herding) and duration of grazing (6 and $9 \mathrm{~h})$ on time expenditure on different activities $\left(\min \mathrm{day}^{-1}\right)$ and ingestion rates by steers in week 6 (August 2005) of the experiment

\begin{tabular}{|c|c|c|c|c|c|c|c|c|}
\hline \multirow[t]{2}{*}{ Variable } & \multicolumn{2}{|l|}{$6 \mathrm{~h}$} & \multicolumn{2}{|l|}{$9 \mathrm{~h}$} & \multirow[t]{2}{*}{ SE } & \multicolumn{3}{|l|}{$p$-values } \\
\hline & Tethered & Herded & Tethered & Herded & & Duration & Method & Interaction \\
\hline Eating & 301 & 289 & 439 & 393 & 7 & $<0.01$ & $<0.01$ & 0.02 \\
\hline Resting & 32 & 40 & 70 & 100 & 7 & $<0.01$ & $<0.01$ & NS \\
\hline Walking & 20 & 21 & 24 & 34 & 3 & $<0.01$ & 0.04 & NS \\
\hline Other & 7 & 10 & 7 & 13 & 1 & NS & $<0.01$ & NS \\
\hline \multicolumn{9}{|l|}{ Ingestion rate } \\
\hline $\mathrm{g} \mathrm{DM} \mathrm{min}^{-1}$ & 12.9 & 16.9 & 8.7 & 12.7 & 1.4 & $<0.01$ & $<0.01$ & NS \\
\hline $\mathrm{mg} \mathrm{OM} \mathrm{kg}{ }^{-0.75} \mathrm{~W} \mathrm{~min}^{-1}$ & 199 & 259 & 145 & 194 & 9 & $<0.01$ & $<0.01$ & NS \\
\hline
\end{tabular}

Note: Eating includes prehension, mastication and search for food; resting refers to time spent resting during while in the grazing site; and other includes activities such as drinking, fighting and socializing. NS $=$ not significant $(p>0.05)$.

by Ayantunde et al. (1999) for a ranch at Toukounous $\left(14^{\circ} 30^{\prime} \mathrm{N}, 3^{\circ} 17^{\prime} \mathrm{E}\right)$, also in Niger. These results confirm that forage availability is not a limiting factor to animal production in the wet season, neither is the quality, as shown by the chemical composition of the herbage grazed in Table 1 (Breman and de Wit, 1983; Glatzle, 1992). However, there is problem of access to pastures in the wet season, especially in agro-pastoral zone in the southern Sahel, due to fragmentation of cultivated fields (Turner and Hiernaux, 2002).

The higher OMD in the esophageally fistulated steers' diets compared to the herbaceous standing herbage reaffirms the selective grazing by the ruminants (Ayantunde et al., 1999; Breman and de Wit, 1983). Breman and de Wit (1983) reported that Zebu cattle diet was 2-5\% higher in crude protein than the standing herbage but this is not supported by the results of this study. Lack of significant difference in crude protein of the standing herbage and the diet selected in this study may be attributed to lower magnitude of difference in nitrogen concentrations at peak vegetative stage among different herbaceous species compared to digestibility (Ayantunde et al., 1999). Besides, the dominance of the same herbaceous species in the parcels grazed could be another reason. Values for crude protein and OMD found in herbage grazed, at peak vegetative stage, are similar to those (crude protein $=112 \mathrm{~g} \mathrm{~kg}^{-1} \mathrm{DM}$; OMD $=617 \mathrm{~g} \mathrm{~kg}^{-1} \mathrm{DM}$ ) reported by Ayantunde et al. (1999) for another location in Niger.

The results on diet quality show that tethering negatively affected digestibility in both periods of extrusa collection. This may be attributed to reduced opportunity for selective grazing due to restricted animal mobility as a result of tethering. Nevertheless, the quality of diet selected even by tethered animals are far higher than 48\% OMD and 5\% crude protein suggested by Breman and de Ridder (1991) as limits for maintenance ration of grazing ruminants in the Sahel. Given that forage quality is generally high in the wet season (Glatzle, 1992), the critical issue is the amount of forage available within the reach of the animal at tethering location. In addition, length of rope, frequency of changing the tethering location and animal species may affect the quality of diet selected. For mature non-productive goats in Tanzania tethered for 4 or $8 \mathrm{~h}$, Romney et al. (1996) reported that tethering had no effect on digestibility of the diet selected. This suggests that the effect of tethering on diet selection may vary with different ruminant species in view of their different grazing behaviour. From the results, the effect of duration of grazing on diet selection is rather not consistent between weeks except for digestibility, in which case there was no effect in both periods. Ayantunde et al. (2001) found similar results in wet season of 1995 that duration of grazing had no effect on dietary selection by grazing steers. The declining quality of the diet selected as the wet season progressed, as observed in this study, has also been reported by Schlecht (1995) for zebu steers grazing natural pastures in Mali.

The non-significant difference in faecal output between 6 and $9 \mathrm{~h}$ of grazing found in this study agree with results by Ayantunde et al. (2001). However, with longer duration of grazing (12-15 h per day), significant effect was reported by the authors. Values found for faecal output in this study agree closely with 27.5 and $28.7 \mathrm{~g} \mathrm{DM} \mathrm{kg}^{-0.75} \mathrm{~W}$ reported for 6 and $9 \mathrm{~h}$ of grazing, respectively, by Ayantunde et al. (2001). Values for nitrogen and phosphorus excretion are also consistent with results by the same authors. The negative effect of 
tethering on faecal output may not be of any consequence to agro-pastoralists in view of the fact that faecal output is only collected during the dry season for manuring crop fields (Powell et al., 1996).

The negative effect of tethering on forage intake found in this study may have resulted from decreasing herbage mass availability and soiling and the effect on selectivity. This suggests that the frequency of changing the tethering location in this study ( 2 to 3 times per day) might not be enough to allow for comparable level of forage intake as in close herded animals. Thus, tethering management (frequency and location) is critical to overcoming the problem of decreasing herbage mass availability within the reach of the tethered animals. The negative effect of tethering on forage intake has also been reported for goats in Tanzania (Romney et al., 1996). Values for forage intake reported in this study agree with findings by Ayantunde et al. (2001) for steers grazing natural pastures in another location in Niger. Lack of significant effect of duration of grazing on forage intake observed for week 6 (August 2005) of the experiment is consistent with results by Ayantunde et al. (2001) for steers grazing 6 and $9 \mathrm{~h}$ per day in August 1995. However, the same authors reported significant effect of duration of grazing on forage intake for longer grazing time (12-15 h per day). The significant effect of duration of grazing in week 9 could be attributed to decline in standing herbage mass and forage quality as the wet season was close to the end. These results suggest that it is advisable to allow the animals to graze for longer time, either tethered or close herded, as the wet season progresses to allow for sufficient forage intake.

Tethering tends to compel the animals to spend the time eating as indicated by the high proportion of the grazing time spent on eating. This advantage of tethering in making the grazing cattle to focus more on eating by minimizing time spent on other activities such as resting, walking, fighting and socializing has been reported by Rachmat et al. (1992) for cattle in South Sulawesi, Indonesia. The effect of duration of grazing on eating time agrees with previous grazing behaviour studies (Ayantunde et al., 2001, 2002; Schlecht et al., 2006) conducted in the region. The proportion of time spent eating by herded animals (about $76 \%$ ) is higher than $66 \%$ reported by Ayantunde et al. (2001) for herded cattle in the dry season in another location in Niger. The difference could be attributed to lower stocking rate in this study $\left(0.6 \mathrm{TLU} \mathrm{ha}^{-1}\right.$ (TLU is tropical livestock unit, a standard animal with a body weight of $250 \mathrm{~kg}$ )) compared to $0.9 \mathrm{TLU} \mathrm{ha}^{-1}$ in the previous study by Ayantunde et al. (2001) which might have reduced time spent walking while in the grazing site, thereby leaving more time for eating. Different herding methods (open herding in the previous study as opposed to close herding in the present study) could be another reason. The effects of herding methods on grazing behaviour of ruminants have been widely reported (Arnold and Dudzinski, 1978; Vallentine, 2001). Higher proportion $(93.5 \%)$ of grazing time spent eating than values found in this study has been reported by Romney et al. (1996) for goats in Tanzania tethered for $4 \mathrm{~h}$ per day.

Higher ingestion rates by animals that grazed for $6 \mathrm{~h}$ compared to those that grazed for $9 \mathrm{~h}$ support the widely reported observation that grazing ruminants tend to compensate for shorter time of grazing by increasing their intake rate and spending a larger proportion of available time eating (Arnold and Dudzinski, 1978; Ayantunde et al., 2001; Romney et al., 1996; Vallentine, 2001). The reason for negative effect of tethering on ingestion rate is unclear. It may probably be attributed to decreasing herbage mass availability within the tethering area.

Lower average daily weight gain by the tethered animals could be explained by lower forage intake than herded animals. The negative effect of tethering may not be noticeable until late dry season (March to June) when there is acute feed shortage and all cattle, except those sufficiently supplemented, lose weight and their survivability at this period largely depends on how much weight they have gained in the wet season (July to September) and crop harvest period (October/November). Lack of effect of duration of grazing on ADG found in this study could be attributed to short grazing time ( 6 and $9 \mathrm{~h})$. In the previous study by Ayantunde et al. (2001) in another location in Niger, long duration of grazing ( $>9 \mathrm{~h}$ per day) had positive effect on weight changes. The weight changes recorded for herded steers fall within the range of $300-500 \mathrm{~g} \mathrm{day}^{-1}$ reported by Achard and Chanono (1995) for free ranging steers in the wet seasons of 1987, 1989 and 1991.

\section{Conclusions}

This study demonstrates that the common practice of tethering sedentary cattle in the wet season in the southern Sahel in West Africa does not have a strong and consistent effect on quality of the diet selected by 
steers but reduces forage intake and consequently average daily weight gain. Given that forage quality is not a limiting factor in the wet season, it is necessary to ensure sufficient herbage mass availability within the tethering area to allow for sufficient forage intake by the animals. This will necessitate changing the tethering location for more than 3 times per day according to results from this study. Frequent movement of the animals does not conflict with labour requirement for cropping activities in the wet season because tethering is often practiced for small cattle herds (on average 3 to 4 head per household). In addition to frequent movement of the tethered animals, it may be necessary to move the tethering location away from the vicinity of the homestead, which is often the practice, to grazing sites where herbage mass availability is high. In view of the acute feed shortage in the late dry season in the Sahel, it is necessary to maximize weight gain during the wet season to enhance survivability of the animals at this critical period and to ensure the overall good productive and reproductive performance of the animals.

\section{Acknowledgements}

We thank Adamou Kalilou, Harouna Garba, Mamoudou Tondi and Mamoudou Issa Koukou of ILRI Niamey, Niger for their outstanding assistance in the field and in laboratory analysis of the extrusa and faecal samples. The study was part of the project "Desert Margins Program (DMP)" partly funded by Global Environment Facility (GEF), with the overall goal of arresting land degradation and conservation of biodiversity in desert margins of sub-Saharan Africa.

\section{References}

Achard, F., Chanono, M., 1995. Un système d'élevage performant bien adaptè à l'aridité Toukounous dans le Sahel nigérien. Sécheresse 6, 215-222.

Arnold, G.W., Dudzinski, M.L., 1978. Ethology of free ranging domestic animals. Development in Animal and Veterinary Sciences, vol. 2. Elsevier Science Publishing, Amsterdam, 198pp.

Ayantunde, A.A., Hiernaux, P., Fernández-Rivera, S., van Keulen, H., Udo, H.M.J., 1999. Selective grazing by cattle on spatially and seasonally heterogeneous rangeland in Sahel. Journal of Arid Environments 42, 261-279.

Ayantunde, A.A., Fernández-Rivera, S., Hiernaux, P.H.Y., van Keulen, H., Udo, H.M.J., Chanono, M., 2001. Effect of timing and duration of grazing of growing cattle in the West African Sahel on diet selection, faecal output, eating time, forage intake and live weight changes. Animal Science 72, 117-128.

Ayantunde, A.A., Fernández-Rivera, S., Hiernaux, P.H., van Keulen, H., Udo, H.M.J., 2002. Day and night grazing by cattle in the Sahel Journal of Range Management 55, 144-149.

Breman, H., de Ridder, N., 1991. Manuel sur les pâturages des pays sahéliens. Karthala/ACCT/CTA, Paris, Wageningen, 485pp.

Breman, H., de Wit, C.T., 1983. Rangeland productivity and exploitation in the Sahel. Science 221, 1341-1347.

Cordova, F.J., Wallace, J.D., Pieper, R.D., 1978. Forage intake by grazing livestock: a review. Journal of Range Management 31 , 430-438.

Fernández-Rivera, S., Salla, A., Hiernaux, P., Williams, T.O., 2003. Transhumance and dry season supplementation for cattle in the Sahel. Journal of Animal Science 81, 15-16.

Fernández-Rivera, S., Hiernaux, P., Williams, T.O., Turner, M.D., Schlecht, E., Salla, A., Ayantunde, A.A., Sangare, M., 2005. Nutritional constraints to grazing ruminants in the millet-cowpea-livestock farming system of the Sahel. In: Ayantunde, A.A., Fernández-Rivera, S., McCrabb, G. (Eds.), Coping with Feed Scarcity in Smallholder Livestock Systems in Developing Countries. International Livestock Research Institute (ILRI), Nairobi, pp. 157-182.

Glatzle, A., 1992. Feed resources in the Sahel. Animal Research and Development 35, 43-58.

Hiernaux, P., 1996. Spatial heterogeneity in Sahelian rangelands and resilience to drought and grazing. In: West, N.E. (Ed.), Rangelands in a sustainable biosphere. Proceedings of the Fifth International Rangeland Congress. Salt Lake City, Utah, pp. $232-233$.

Hiernaux, P., Ayantunde, A., 2004. The Fakara: a semi-arid agro-ecosystem under stress. Report of Research Activities of International Livestock Research Institute (ILRI) in Fakara, South-western Niger, between 1994 and 2002, Desert Margins Program Report, ICRISAT Niamey, Niger, 95pp.

Hiernaux, P., Bielders, C.L., Valentin, C., Bationo, A., Fernández-Rivera, S., 1999. Effects of livestock grazing on physical and chemical properties of sandy soils in Sahelian rangelands. Journal of Arid Environments 41, 231-245.

Menke, K.H., Raab, L., Salewski, A., Steingass, H., Fritz, D., Schneider, W., 1979. The estimation of the digestibility and metabolizable energy content of ruminant feeding stuffs from gas production when they are incubated with rumen liquor in vitro. Journal of Agricultural Science 93, 217-222.

Powell, J.M., Fernández-Rivera, S., Hiernaux, P., Turner, M.D., 1996. Nutrient cycling in integrated rangeland/cropland systems of the Sahel. Agricultural Systems 52, 143-170. 
Rachmat, R., Stür, W.W., Blair, G.J., 1992. Cattle feeding systems and limitations to feed supply in South Sulawesi, Indonesia. Agricultural Systems 39, 409-419.

Romney, D.L., Sendalo, D.S.C., Owen, E., Mtenga, L.A., Penning, P.D., Mayes, R.W., Hendy, C.R.C., 1996. Effects of tethering management on feed intake and behaviour of Tanzanian goats. Small Ruminant Research 19, 113-120.

SAS, 1987. SAS/STAT for Personal Computers. SAS Institute, Cary, NC, 1027pp.

Schlecht, E., 1995. The influence of different levels of supplementation on feed intake and nutrient retention of zebu cattle in Sahelian agro-pastoral systems. Ph.D. Thesis, University of Hohenheim, Hohenheim, Germany, 200pp.

Schlecht, E., Hiernaux, P., Kadaoure, I., Hülsebusch, C., Mahler, F., 2006. A spatio-temporal analysis of forage availability and grazing and excretion behaviour of herded and free grazing cattle, sheep and goats in Western Niger. Agriculture, Ecosystems and Environment 113, 226-242.

Thebaud, B., Batterbury, S., 2001. Sahel pastoralists: opportunism, struggle, conflict negotiation. A case study from eastern Niger. Global Environmental Change 11, 69-78.

Turner, M.D., Hiernaux, P., 2002. The use of herders' accounts to map livestock activities across agro-pastoral landscapes in semi-arid Africa. Landscape Ecology 17, 367-385.

Turner, M.D., Hiernaux, P., Schlecht, E., 2005. The distribution of grazing pressure in relation to vegetation resources in semi-arid West Africa: the role of herding. Ecosystems 8, 668-681.

Vallentine, J.F., 2001. Grazing Management, second ed. Academic Press, San Diego, CA, 659pp.

Van Soest, P.J., Robertsons, J.B., Lewis, A.B., 1991. Methods for dietary fibre, and non-starch polysaccharides in relation to animal nutrition. Journal of Dairy Science 74, 3583-3597. 